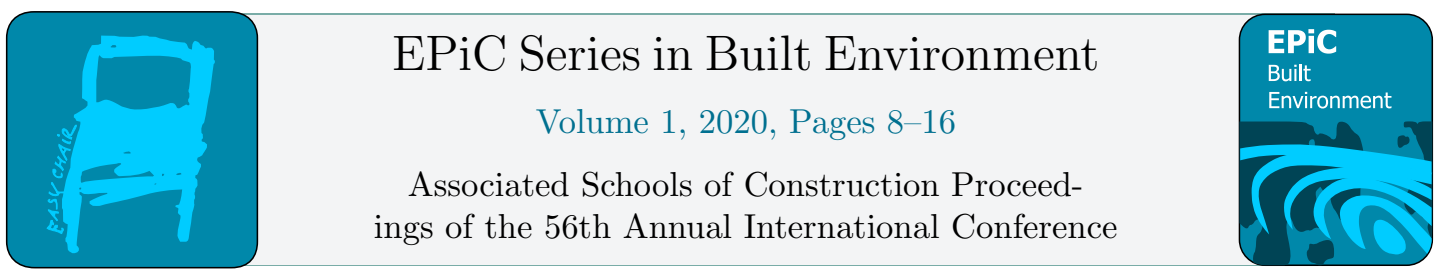

\title{
Demographic Challenges Ahead for Construction Education
}

\author{
C. Ben Farrow, P.E., Ph.D. \\ Auburn University \\ Auburn, Alabama
}

The construction economy is strong, and many construction management programs are experiencing record attendance. However, the coming decline within the U.S. in the number of college students (15\% decline beginning in 2026) looms large. This exploratory research project seeks to illuminate the potential impact of this demographic shift in five states where a diversity of construction management and geography exists: Alabama, Colorado, Illinois, Texas, and Washington. Results indicate substantial drops in enrollment for schools in Alabama and Illinois and illuminate that almost all regional universities will suffer as a result of the anticipated demographic shifts. Construction management programs should prepare for the coming shifts and increased competition for students. Options include additional emphasis on growing demographic sectors, an additional focus on gender diversity, and shifts in instructional approaches.

Key Words: Construction Education, Demographics, Student Recruitment, Enrollment

\section{Introduction}

The recession of 2007-09 had significant impacts on construction education. For many institutions, enrollment in construction management programs dropped, and companies recruiting for available graduates plummeted as demand for construction waned (Binke, 2018). During that period, birth rates within the U.S. also fell almost 13\% over a five-year period (Grawe, 2018). The Chronicle of Higher Education detailed the impact of this demographic shift in a lead story in January 2014, with a headline entitled "The Class of 2030" (Lipka, 2014). The article stated, "Until just a few years ago, colleges could expect classes of high school graduates each bigger than the last... these days are over." (Lipka, 2014, p. A24) Beginning in 2026, the number of college-aged students will fall approximately $15 \%$ in five years (Grawe, 2018). In addition to fewer people of college-age, migration patterns and immigration changes will also impact future numbers of college students.

A recently published book entitled Demographics and the Demand for Higher Education (Grawe, 2018) has gained popularity among University recruiters and administrators for its detailed analysis predicting future college enrollments. Grawe's "Higher Education Demand Index (HEDI)" examined data to predict future enrollment of colleges based on factors including "sex, race/ethnicity, parent education, geographic location, family income, family composition, and nativity". 
This introductory study seeks to illuminate how Grawe's projected demographic shifts may impact construction management programs in five states (Alabama, Colorado, Illinois, Texas, and Washington) within five of the nine U.S. census regions. These states were selected since they provided some diversity in both types of construction management programs (All states selected had multiple and varied construction degree programs) and in geographic areas (one state per census region) of the country while keeping the number of institutions reasonable for this exploratory study. Decisions over the next five years on how to address this pending demographic shift will be critical to the future of construction education. A wide variety of potential responses may be available including targeted student recruitment, shifts toward adjunct faculty, the use of technology in teaching, and additional funding directed toward attendance of groups with lower matriculation rates. A better understanding of specific implications of the demographic shifts may impact these decisions. Specifically, this research project seeks to answer three questions:

- What are the potential impacts on number of graduates for construction programs in Alabama, Colorado, Illinois, Texas, and Washington based on current program enrollment by 2029 ?

- Are some construction management programs currently predicted to "win" with demographic shifts while some are set up to "lose"?

- Do obvious opportunities exist for universities in these states to expand current student demographics?

\section{Literature Review}

One of the most significant contributions of Nathan Grawe's book entitled Demographics and the Demand for Higher Education is that "because college-going probabilities are so heterogeneous, simple population forecasts alone are of limited value in predicting demand for college" (Grawe, 2018, p. 31). No previous study considered the probability of college attendance or what type of institution graduates may select (Grawe, 2018; Lipka, 2014; Selingo, 2018). When the probability of attendance is considered, potential negative demographic trends are reversed for some schools and magnified for others. Grawe suggests that it may be time for universities to consider altering their size and/or which programs they plan to support. Others have suggested new recruitment strategies, changes in curricula, new pedagogy, and expanded support services (McPherson, 2017).

\section{Fertility Rates, Immigration, Interstate Migration}

Three fundamental demographic shifts appear to be primary drivers of the future pool of traditional college students. These include fertility rates, immigration, and interstate migration (Grawe, 2018). In what appears to be a response to the financial recession that began in 2007, the nation's overall fertility rate has plummeted by more than $12 \%$ (Grawe, 2018, p. 6). Other reasons for the drop in fertility rates include the rise of women in the workforce and the corresponding opportunity cost of having children (Golden and Katz, 2006). This fertility rate drop will manifest itself beginning in 2026 as the students born in 2007 will matriculate to college, and a rapid decline in college-age students will begin. Only eight states have an overall fertility rate that is predicted to maintain the current state population. (Grawe, 2018, pp. 10-11).

Population changes and the pool of available college-aged students also change as a result of immigration. Approximately one million people become U.S. residents each year (Homeland Security Yearbook of Immigration Statistics: 2015). In addition to the legal residents, estimates predict another $20 \%$ of unauthorized immigrants (Hoefer, 2012). For those that do immigrate to the United States, research suggests that people moving into the U.S. often congregate in specific areas of the country. 
Most notably, those areas are where other non-residents reside. In addition, areas with immigration friendly legislation also draw populations (Bartel, 1989; Razin \& Wahba, 2015).

Within the U.S., populations shift. Currently, there is a migration of people out of the Northeast into the South and West. In addition, populations in the Pacific area are shifting South. Specifically, growth in the South appears to be focused toward the Southwest and especially the Hispanic Southwest (Grawe, 2018). For the states considered in this study, Alabama (-2.5\% to $-7.5 \%)$ and Illinois (more than -15\%) are expected to see declines in the forecasted number of high school graduates while Colorado ( $>7.5 \%$ increase), Texas ( $>7.5 \%$ increase), and Washington $(>7.5 \%$ increase), see increases in these same numbers (Grawe, 2016).

\section{Geographic and Ethnic Shifts}

The Western Interstate Commission for Higher Education (WICHE) predicts a five percent rise in the number of high school graduates through 2025 followed by a sharp and immediate $9 \%$ drop ("Knocking at the college door: Projections of high school graduates," 2016). While a five percent growth sounds positive, WICHE shows this growth almost exclusively in the Mountain and West South-Central Census areas. When geographic regions are considered, the West South-Central is the only census area that is up while the Pacific, Middle Atlantic, and New England drop 32,000 to 54,000 students. The East North Central is predicted to fall more than 90,000 students (Grawe, 2018). As entire regions of the country experience enrollment drops, challenges are created for recruiters as one school cannot replace lost students by simply shifting to adjacent states.

By 2032, WICHE predicts 265,000 (15\%) fewer non-Hispanic white high school graduates in the U.S., a group that currently is the largest source of students for construction programs. Non-Hispanic white students will decrease almost uniformly across the U.S. In the Midwest and Northeast, this is predicted to be significant as these students have the highest propensity to attend college. Asian and Pacific Islander graduates are forecast to increase by $35 \%$ in the same time period. (Grawe, 2018). The overall trends for non-Hispanic black students is negative with their share of college students predicted to fall from $13 \%$ to $10 \%$ (20\% drop) by 2029 . This decline in non-Hispanic black students will exceed 15\% in Illinois, Texas, and Alabama by 2029 (Grawe, 2018).

\section{College Attendance Across Census Divisions}

The demand for college education does not directly mirror population trends. Some geographic regions have higher percentages of students attending college. For example, a high school graduate in the Northeast is $40 \%$ more likely to attend college than a student from the West or South. When highly ranked institutions are considered, this regional difference is more significant. A student from New England has a chance at least 10 times greater to attend a top 50 school as compared to a student from the South or West (Grawe, 2018).

Children from households where parents attended college, and/or parents have a higher income, are more likely to attend college. For a student that has at least one parent who attended college, that student is more than twice as likely to attend college than a student who does not have a parent that attended college. "When compared with children in families earning less than $\$ 50 \mathrm{~K}$ per year in 2002 , children in families with income above $\$ 100 \mathrm{~K}$ are $50 \%$ more likely to attend a postsecondary institution of some type." (Grawe, 2018, p. 24)

While much attention has been focused on first-generation college students, the demand for a college education from this demographic is predicted to fall in all but elite institutions (Grawe, 2018). The 
U.S. will see a $5 \%$ drop in first-generation students while the number of students who have two parents with college degrees with increase $7 \%$. Grawe argues that some of this may be due to the large numbers of first-generation students who have attended college during the past few decades.

\section{Demand for Construction Managers}

While the number of college graduates is anticipated to fall, the same cannot be said for the demand for construction managers. The U.S. Bureau of Labor Statistics estimates that total employment of construction managers will be approximately 518,000 in 2028 as compared to 471,800 in $2018(10 \%$ net increase) ("Employment Projections," 2018). Further, they predict this net increase will occur in primary areas of "construction of buildings" and "specialty trade contractors".

\section{Method}

Grawe's research utilized the "Higher Education Demand Index" model. The model was tested using the 2000 Census and proved effective in anticipating the number matriculating to college in subsequent years. The model's basic premise is that the demand for college will equal the probability of attendance times the number of children (by year and location)(Equation 1)(Grawe, 2018, p. 28):

$$
\begin{gathered}
\text { Demand for College }= \\
\mathrm{P}_{11} \mathrm{~N}_{11 \mathrm{t}}+\mathrm{P}_{12} \mathrm{~N}_{12 \mathrm{t}}+\mathrm{P}_{13} \mathrm{~N}_{13 \mathrm{t}}+\ldots \mathrm{P}_{\mathrm{lk}} \mathrm{N}_{1 \mathrm{kt}}
\end{gathered}
$$

where $\mathrm{l}=$ location, $\mathrm{t}=$ time, $\mathrm{k}=$ demographic type, $\mathrm{P}=$ probability that a student from a given demographic will attend college, and $\mathrm{N}=$ number of students in a given demographic

The model only attempts to predict the number of students who have demographic parameters associated with college attendance. This may be different than the number of students who actually attend college as universities adjust admission standards to reach a targeted class size. While HEDI separated institutional types ( 2 or 4 year and regional, national, and elite colleges), this project focused only on institutions awarding a 4-year bachelor's degree. Institutions ranking in the top 50 of U.S. News \& World Report were termed "elite", those ranked between 51 and 100 were termed "national", and those falling below 100 were termed "regional" institutions (Grawe, 2018, p. 29).

\section{Base Data for Construction Students}

The National Center for Education Statistics (IPEDS database) was used to compile the number of construction graduates in the states of interest during the 2017-18 academic year ("National Center for Educational Statistics," n.d.). This year corresponded to the timeframe associated with the base numbers Grawe used to predict future numbers of college students. The number of graduates was used in lieu of number of enrolling students as this number was a direct function of enrolling students, was readily available through the IPEDS database, and provides a more stable number of students over time at discrete universities. Majors considered in this research were based on Classification of Instructional Program (CIP) Codes per the U.S. government database. Codes considered included construction management (52.2001), construction engineering technology (15.1001), architectural engineering (14.0401), and construction engineering (14.3301).

\section{Calculating Predicted Numbers}

Results from the IPEDS database yielded number of graduates for each program with a corresponding CIP code. Numbers of graduates were separated for each university by sex and race/ethnicity for 
purposes of the analysis and placed in a spreadsheet. For changes in overall number of students, this study used Grawe's predicted percentage change for the specific census region of the country where the school was located. With nine total census areas available, this focused the study in five specific areas (Pacific, Mountain, West South Central, East South Central, and East North Central). The assumption to use data for each census area is consistent with Grawe's data that the majority of students attending regional institutions (majority of study) travel no more than 150 miles to attend college (Grawe, 2018, p. 70). The assumption was also used for "national" and "elite" institutions as directional with the understanding that additional error was likely for these institutions as Grawe predicts at least $25 \%$ of their student body will travel more than 220 miles to attend college. The predicted percentage change for institution type and census region was multiplied by the number of graduates in 2017-18 to predict a possible number of graduates by 2029.

For changes in specific demographics (by race/ethnicity), Grawe's raw data was obtained for the predicted number of students in each category by type of institution (Grawe, 2016). Calculations were made within a spreadsheet that determined the percentage change predicted by 2029 for Asian Americans, Hispanic, and all other race/gender categories. This separation of demographic was utilized as the data indicated significant changes in the Asian American and Hispanic categories.

\section{Results}

This exploratory research project sought to utilize Grawe's data coupled with IPEDS data on the number of existing construction graduates in five states to better understand the potential impact of the anticipated demographic shift in students attending college beginning in 2026. The five states and corresponding census regions considered were Alabama (East South-Central), Colorado (Mountain), Illinois (East Central), Texas (West South-Central), and Washington (Pacific). Based on IPEDS data, the following institutions and graduates were identified (Table 1).

Table 1

Descriptive Statistics of Demographic Evaluated

\begin{tabular}{ccccc}
\hline State & School & $\begin{array}{c}\text { Grawe } \\
\text { Category }\end{array}$ & $\begin{array}{c}\text { Degree (Based on CIP } \\
\text { Code) }\end{array}$ & $\begin{array}{c}\mathbf{2 0 1 7 -} \\
\mathbf{1 8} \\
\text { Grads }\end{array}$ \\
\hline AL & Auburn University & Regional & Architectural Engineering & 104 \\
AL & Tuskegee University & Regional & Construction Management & 14 \\
AL & University of Alabama-Tuscaloosa & Regional & Arch. Egr/Const. Egr & 31 \\
CO & Colorado Mesa University & Regional & Construction Egr Tech & 27 \\
CO & Colorado State-Fort Collins & Regional & Construction Egr Tech & 148 \\
CO & Colorado State University-Pueblo & Regional & Construction Management & 11 \\
CO & University of Colorado Boulder & Regional & Architectural Engineering & 32 \\
CO & University of Denver & National & Construction Management & 1 \\
IL & Bradley University & Regional & Construction Engineering & 22 \\
IL & Illinois Institute of Technology & Regional & Architectural Engineering & 4 \\
IL & Illinois State University & Regional & Construction Management & 50 \\
IL & Western Illinois University & Regional & Construction Management & 19 \\
TX & Lamar University & Regional & Construction Engineering & 10 \\
TX & Prairie View A \& M University & Regional & Construction Egr Tech & 19 \\
TX & Sam Houston State University & Regional & Construction Egr Tech & 48
\end{tabular}




\begin{tabular}{cclcc} 
TX & Tarleton State University & Regional & Construction Egr Tech & 7 \\
TX & Texas A \& M -College Station & National & Construction Egr Tech & 315 \\
TX & Texas A \& M -Commerce & Regional & Construction Engineering & 14 \\
TX & Texas A \& M University-Kingsville & Regional & Architectural Engineering & 12 \\
TX & Texas State University & Regional & Construction Egr Tech & 99 \\
TX & Texas Tech University & Regional & Construction Engineering & 29 \\
TX & The University of Texas-Arlington & Regional & Architectural Engineering & 3 \\
TX & The University of Texas at Austin & Elite & Architectural Engineering & 36 \\
TX & The University of Texas at El Paso & Regional & Construction Engineering & 7 \\
TX & The University of Texas at Tyler & Regional & Construction Management & 20 \\
TX & University of Houston & Regional & Construction Egr Tech & 120 \\
TX & University of North Texas & Regional & Construction Egr Tech & 24 \\
WA & Central Washington University & Regional & Construction Management & 31 \\
WA & University of Washington & National & Arch. and Bldg Sci/Tech & 65 \\
WA & Washington State University & Regional & Construction Management & 45 \\
\hline
\end{tabular}

What are the potential impacts on number of graduates for construction programs in Alabama, Colorado, Illinois, Texas, and Washington based on current program enrollment by 2029 ?

Based on census division, regional schools in Illinois and Alabama are predicted to have the biggest reductions in enrollment with $24 \%$ and $21 \%$ drops. Slight increases are predicted for schools in Washington State while a significant increase in predicted number of students occurs at the University of Texas due to its favorable location and classification as a top 50 university by U.S. News \& World Report. The percent increase or decrease predicted per census region was multiplied by the number of 2017-18 graduates in Table 1 to obtain the "predicted total change of students" shown in Table 2. In absolute numbers, the numbers for some of the larger programs appear grim. Auburn could lose 22 students per year or 88 students over four years. Illinois State could fall approximately eight students per year or 32 students over four years. Both of these aggregate four-year numbers represent approximately an entire graduating class in a single year currently.

Table 2

Predicted Change in Number of CM Graduates

\begin{tabular}{ccc}
\hline University & $\begin{array}{c}\text { Predicted Overall } \\
\text { Change \% }\end{array}$ & $\begin{array}{c}\text { Predicted Total Change } \\
\text { of students }\end{array}$ \\
\hline Auburn University & $-21 \%$ & -22 \\
Tuskegee University & $-21 \%$ & -3 \\
University of Alabama-Tuscaloosa & $-21 \%$ & -7 \\
Net Change for Alabama & & $-\mathbf{3 2}$ \\
Colorado Mesa University & $-6 \%$ & -2 \\
Colorado State University-Fort Collins & $-6 \%$ & -9 \\
Colorado State University-Pueblo & $-6 \%$ & -1 \\
University of Colorado Boulder & $-6 \%$ & -2 \\
University of Denver & $16 \%$ & 0 \\
Net Change for Colorado & & $\mathbf{- 1 3}$ \\
Bradley University & $-24 \%$ & -5 \\
Illinois Institute of Technology & $-24 \%$ & -1 \\
Illinois State University & $-24 \%$ & -12 \\
Western Illinois University & $-24 \%$ & -5
\end{tabular}




\begin{tabular}{ccc} 
Net Change for Illinois & & $\mathbf{- 2 3}$ \\
Lamar University & $-4 \%$ & 0 \\
Prairie View A \& M University & $-4 \%$ & -1 \\
Sam Houston State University & $-4 \%$ & -2 \\
Tarleton State University & $-4 \%$ & 0 \\
Texas A \& M University-College Station & $-1 \%$ & -3 \\
Texas A \& M University-Commerce & $-4 \%$ & -1 \\
Texas A \& M University-Kingsville & $-4 \%$ & 0 \\
Texas State University & $-4 \%$ & -4 \\
Texas Tech University & $-4 \%$ & -1 \\
The University of Texas at Arlington & $-4 \%$ & 0 \\
The University of Texas at Austin & $228 \%$ & 82 \\
The University of Texas at El Paso & $-4 \%$ & 0 \\
The University of Texas at Tyler & $-4 \%$ & -1 \\
University of Houston & $-4 \%$ & -5 \\
University of North Texas & $-4 \%$ & -1 \\
Net Change for Texas & & $\mathbf{6 3}$ \\
Central Washington University & $1 \%$ & 0 \\
University of Washington & $9 \%$ & 6 \\
Washington State University & $1 \%$ & 0 \\
Net Change for Washington & & $\mathbf{6}$ \\
\hline
\end{tabular}

Are some construction management programs currently predicted to "win" with demographic shifts while some are set up to "lose"?

While there are schools that have ominous forecasts, there are few winners when Grawe's data is applied to existing construction management graduates. The University of Texas is expected to have significant positive gains ("elite" university in positive market) while schools in Washington State will remain stable or have modest gains. All other schools are predicted to lose students (Table 3).

Table 3

Winners vs. Losers in Predicted Demographic Change in Construction Management (Number of Students)

\begin{tabular}{cc}
\hline Schools with Positive Changes & Schools with Negative Changes \\
\hline The University of Texas at Austin (82) & Auburn University (-22) \\
University of Washington (6) & Tuskegee University (-3) \\
University of Alabama (-7) \\
Colorado Mesa University (-2) \\
Colorado State University-Fort Collins (-9) \\
Colorado State University-Pueblo (-1) \\
University of Colorado Boulder (-2) \\
Bradley University (-5) \\
Illinois Institute of Technology (-1) \\
Illinois State University $(-12)$ \\
Western Illinois University $(-5)$ \\
Prairie View A \& M University $(-1)$ \\
Sam Houston State University $(-2)$ \\
Texas A \& M University-College Station $(-3)$
\end{tabular}


Texas A \& M University-Commerce (-1) Texas State University (-4)

Texas Tech University (-1)

The University of Texas at Tyler (-1)

University of Houston (-5)

University of North Texas (-1)

Do obvious opportunities exist for universities in these states to expand current student demographics?

Opportunities do exist for all construction management programs to restructure recruiting, scholarship, and admissions approaches to attract additional students in the predicted competitive market for students. Specific opportunities are evident for the recruitment of students outside traditional demographics including Hispanic, Asian, and other non-white designations (Table 4).

Table 4

Predicted Changes in Specific Demographic Areas for CM Programs

\begin{tabular}{lccc}
\hline School & $\begin{array}{c}\text { Predicted } \\
\text { Change in } \\
\text { Hispanic } \\
\text { Students }\end{array}$ & $\begin{array}{c}\text { Predicted } \\
\text { Change in } \\
\text { Asian } \\
\text { Students }\end{array}$ & $\begin{array}{c}\text { Predicted } \\
\text { Changes in } \\
\text { Other Non- } \\
\text { white Students }\end{array}$ \\
\hline All Alabama schools in this study & $90 \%$ & $-44 \%$ & $-32 \%$ \\
All Colorado schools in this study except & $-5 \%$ & $2 \%$ & $5 \%$ \\
University of Denver & $-7 \%$ & $72 \%$ & $82 \%$ \\
All Illinois schools in this study & $0 \%$ & $1 \%$ & $-27 \%$ \\
All Texas schools in this study except & $11 \%$ & $38 \%$ & $-12 \%$ \\
Texas A \& M-College Station & $5 \%$ & $89 \%$ & $16 \%$ \\
The University of Texas at Austin & $120 \%$ & $370 \%$ & $344 \%$ \\
All Washington schools in this study except & $16 \%$ & $-4 \%$ & $3 \%$ \\
University of Washington & $26 \%$ & $27 \%$ & $54 \%$ \\
\hline
\end{tabular}

When the demographics above are considered based on 2017-18 graduates, little if any change would develop as a result of the demographic change unless an increase in the percentage studying construction management changes. For example, Auburn University is predicted to see as much as $90 \%$ increase in the number of Hispanic students, but based on current metrics, only one student that graduated in 2017-18 identified as Hispanic.

\section{Analysis and Conclusions}

The pending shift in student demographics beginning in 2026 presents a stark reality for many universities as competition for students will increase, and enrollment will fall. Many construction management programs will find themselves in competition for students at a greater degree than exists today. It appears there will be winners and losers in this demographic shift. Universities in the Mountain, Pacific, and Southwest areas will be impacted less than those in the Northeast, Southeast or East Central. However, most regional four-year institutions with construction management programs (majority of CM programs) will experience loses in enrollment. 
For those with excess demand for the major currently, perhaps this can be absorbed. For others, the changes could be minimal to catastrophic. It is unknown how Universities may respond to budgetary challenges as numbers fall. Smaller programs which often include construction management sectors could be in danger of extinction as universities shift to reduce personnel costs. Could shifts to adjunct faculty or professors of practice in lieu of permanent tenure-track faculty provide an opportunity to alleviate long-term salary pressure while increasing experience in the classroom be an option?

Even for schools that are "winners", competition for construction management students will be significant. Construction management programs must continue to work with industry to develop a more robust method to identify construction management as a diverse, growing, positive opportunity for college students. Specifically, the existing lack of diversity in construction management programs could be an additional detriment to anticipated demographic shifts. Without the ability to effectively recruit women (only 17\% of the CM graduates in 2017-18 in this study), Hispanics, and Asians at a high rate into construction management programs, the pending demographic shift could be more substantial. In addition, schools should consider opportunities to increase enrollment in non-degree offerings such as "certificates" or "badges" which could provide opportunities for struggling programs to attract additional students. In sum, the status quo approach to enrollment in the years ahead will likely lead to problems for almost all construction management programs.

\section{References}

Bartel, A. P. (1989). Where do the new US immigrants live? Journal of Labor Economics, 7(4), 371391.

Binke, B. (2018, August 28). Why is there a construction labor shortage? Retrieved from Construction Today website: https://www.construction-today.com/editor-s-blog/3495-why-is-there-aconstruction-labor-shortage

Employment Projections. (2018). Retrieved from U.S. Bureau of Labor Statistics website: https://www.bls.gov/ooh/management/construction-managers.htm\#tab-6

Grawe, N. D. (2016). Supplemental materials for demographics and the demand for higher education. Retrieved from Carleton University faculty page -Grawe website: https://people.carleton.edu/ ngrawe/HEDI.htm

Grawe, N. D. (2018). Demographics and the demand for higher education. Baltimore: John Hopkins University Press.

Knocking at the college door: Projections of high school graduates. (2016, December). Retrieved from Western Interstate Commission for Higher Education website: https://knocking.squarespace.com/reports/2017/3/22/full-report

Lipka, S. (2014, January 24). Colleges, here is your future. Chronicle of Higher Education, pp. A24A27.

McPherson, P. (2017, June 6). Our college students are changing. Why aren't our higher education policies? The Washington Post. Retrieved from https://www.washingtonpost.com/opinions/our-college-students-are-changing-why-arentour-higher-education-policies/2017/06/06/1fc0e37c-3678-11e7-b41262beef8121f7_story.html

National Center for Educational Statistics. (n.d.). Retrieved from Integrated Postsecondary Data System website: https://nces.ed.gov/ipeds/

Razin, A., \& Wahba, J. (2015). Welfare magnet hypothesis, fiscaal burden, and immigration skill selectivitiy. Scandinavian Journal of Economics, 117(2), 369-402.

Selingo, J. (2018, January 28). Higher education is headed for a supply and demand crisis. The Washington Post. Retrieved from https://www.washingtonpost.com/news/gradepoint/wp/2018/01/27/higher-education-is-headed-for-a-supply-and-demand-crisis/ 